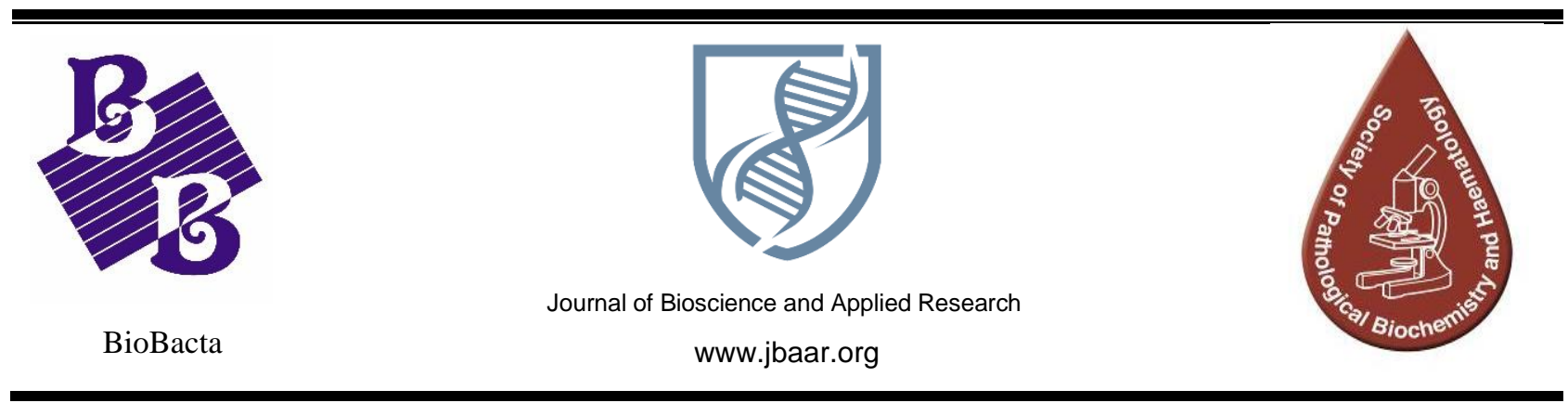

\title{
Citicoline Ameliorates Neuro- and Genotoxicity Induced by Acute Malathion
}

\section{Intoxication in Rats}

\section{Asmaa F. Galal ${ }^{\text {* }}$, Lamiaa M. Salem², Mahrousa M. Hassanane², Somaia A. Nada ${ }^{3}$, Omar M. E. Abdel-Salam ${ }^{1}$}

${ }^{1}$ Narcotics, Ergogrnics and Poisons Department, National Research Centre, Giza, Egypt. Affiliations ID: 60014618.

${ }^{2}$ Department of Cell Biology, National Research Centre, Giza, Egypt. Affiliations ID: 60014618.

${ }^{3}$ Pharmacology Department, National Research Centre, Giza, Egypt. Affiliations ID: 60014618.

*Corresponding author: Asmaa F. Galal

Narcotics, Ergogrnics and Poisons Department, National Research Centre, Giza, Egypt, P.O 12622, Tel: +2 02 33371615, Fax: +202 33370931, E-mail:asma.galal.79@gmail.com

DOI: 10.21608/jbaar.2019.146800

\begin{abstract}
Objective: In the present study, we explored the therapeutic potential of citicoline in preventing malathion induced neurotoxicity and genotoxicity. Citicoline has been shown to act as a neuroprotective in experimental animal models of ischemia and other types of brain injuries. Methods: Acute malathion intoxication was induced by intraperitoneal injection of malathion $(150 \mathrm{mg} / \mathrm{Kg}$, once per day) for two successive days. Citicoline was co-administered in three doses (100, 200, $300 \mathrm{mg} / \mathrm{kg}$, p.o.). Serum Butyrylcholine esterase (BChE) and Paraoxonase-1 (PON-1) were assessed as exposure biomarkers. Oxidative stress biomarkers were assessed in the different brain regions (cortex, striatum, and subcortex) in addition to TNF- $\alpha$. Genotoxicity was tested by chromosomal aberrations, mitotic index, DNA fragmentation, and micronucleus tests. Results: Malathion administration resulted in marked suppression of serum $\mathrm{BChE}$ and PON-1 activities. Also, the exposure to the pesticide led to elevated malondialdehyde (MDA), nitric oxide (NO), and decreased reduced glutathione (GSH) levels in investigated brain regions in addition to elevated striatal tumor necrosis factor- $\alpha$ (TNF- $\alpha$ ) level. Malathion also caused profound structural chromosomal aberrations, increased liver DNA fragmentation, and mitotic index. These effects were alleviated with the administration of citicoline dosedependently. Conclusion: Our data indicate that citicoline can protect against malathion neurotoxic and genotoxic potential, possibly through antioxidant, anti-inflammatory activities, and restoring energy stores.
\end{abstract}

Keywords: Malathion; Citicoline; Cytogenic damage; Oxidative stress; Inflammatory cytokines 


\section{INTRODUCTION}

Organophosphate pesticides are potent toxicants that pose serious threats to health and the environment. The World Health Organization estimated the yearly death due to pesticide intoxication by 250,000 people in developing countries (WHO, 2018). People in developing countries are at higher risk of pesticide poisoning owing to ease of access, poor working environment, and lack of awareness of its potential hazards. In Egypt, OPs account for $55 \%$ of pesticide poisoned cases in poison centers (Abdou and Abo El-Atta, 2018). Abd-El Al et al. (2016) surveyed acutely OPsintoxicated patients admitted to Poison Control Centre, Ain Shams University, Egypt, and found that $46 \%$ of patients were exposed due to suicidal attempts, $40 \%$ were accidentally exposed and $14 \%$ were due to occupational exposure. Malathion has been widely used as an OP pesticide because of its relatively low toxicity and low environmental persistence compared to other OPs and organochlorine pesticides. Malathion binds with acetylcholinesterase (AChE), an enzyme responsible for normal nerve function, resulting in the accumulation of acetylcholine (Ach) with the subsequent stimulation of cholinergic, nicotinic, and muscarinic receptors (Chen, 2012). Common early signs of exposure include irritation of the skin, abdominal cramps, numbness, headache, difficulty breathing, tingling sensation, dizziness, exacerbation of asthma, and weakness. These symptoms can exaggerate to long-term, chronic neurological disorders such as Parkinson's disease (Jenner, 2001), amyotrophic lateral sclerosis (Guillette et al., 1998), and memory impairment (Gauthier et al., 2001). The ability of malathion and other OP pesticides to produce genomic toxicity has been demonstrated both in vitro and in vivo, as well as in epidemiological studies (Moore et al., 2011). Over the years, triggered effects due to such genotoxicity may include carcinogenic, neurological, and reproductive processes that are considered as a primary risk factor. Besides, mutagenic and non-mutagenic processes may induce genetic alterations because of the use of pesticides. Workers exposed to pesticides are at increased risk of different types of carcinomas such as Leukemia (Bonner et al., 2010), Hodgkin's lymphoma (Orsi et al., 2009), non- Hodgkin's lymphoma (Orsi et al., 2009; Bertrand et al., 2010), multiple lymphoma (Baris et al., 2004), lung cancer (Beane Freeman et al., 2005), pancreatic cancer (Andreatti et al., 2009), bladder and colon cancer (Koutros et al., 2009), and gastric cancer (Mills and Yang, 2007).

Oxidative stress is suggested to be the mechanism of pesticide toxicity that induces health risks including cancer and neurodegenerative diseases. Reactive oxygen species (ROS) can play a critical role in suppressing defense mechanisms and can cause aging by the gradual accumulation of free radical damage to biomolecules. Exposure to pesticides is reported to affect antioxidant capacity with deterioration in its defense mechanisms, as well as an increase in lipid peroxidation. Also, pesticides are known to potentiate the production of free radicals (Astiz et al., 2011; Abdollahi and Karami-Mohajeri, 2012).

Moreover, OPs intoxication stimulates proinflammatory mediators leading to neural injury and neurological impairment, and its inflammatory responses in the injured brain progress for days from onset time of symptoms (Singh and Jiang, 2003). In experimental studies, such inflammatory effects of pesticides impair cell survival and enhance neuronal excitability (Rohlman et al., 2011; Li et al., 2015).

The current therapeutic intervention for $O P$ poisoning is mainly useful for reducing peripheral signs of cholinergic crisis but are not able to halt long-term neurological damage. Therefore, more effective therapeutic strategies against OPs pesticides must be developed to improve emergency treatment and protection of the following sequelae.

Citicoline, cytidine-5'-diphosphocholine, or CDPcholine is a naturally occurring endogenous nucleoside that combines neurovascular protection and brain repair effect. Interest in its brain protective effects has increased recently owing to its high bloodbrain barrier (BBB) penetration besides the good profile of adverse events (Adibhatla and Hatcher, 2005; Grieb, 2014). Citicoline is currently administrated as part of medical intervention in order 
to enhance recovery and minimize secondary damage in brain stroke, head trauma, and other neurological disorders such as dementia and transient ischemic attack (Saver, 2008; Secades, 2011; Secades, 2016). When administered exogenously, citicoline provides both choline and cytidine; substrates for the synthesis of phosphatidylcholine (PtdCho). PtdCho can promote membrane synthesis and repair, which are the main events in recovery from neuronal injury (Adibhatla and Hatcher, 2005). Citicoline improved neurological outcomes in a rat model of cerebral ischemia by suppressing neuronal membrane breakdown and toxic products of tissue damage following an ischemic insult. Citicoline treatment reduced the volume of ischemic lesions and improved structural integrity of the brain, neurological symptoms, psychomotor deficits, EEG activity, and general quality of life (Levin, 1991; Warach et al., 2000).

In the experimental model of traumatic brain injury, citicoline treatment resulted in reducing blood-brain barrier breakdown and brain edema (Baskaya et al., 2000). Citicoline treatment also improved motor function and neural plasticity in experimental stroke in rats (Hurtado et al., 2007).

The present work was undertaken to investigate the ability of citicoline to combat neurotoxic and genotoxic sequalae of acute malathion intoxication. Exposure biomarkers to OPs, brain oxidative stress biomarkers, and inflammatory cytokine such as TNF$\alpha$ were assayed. Chromosomal aberrations, mitotic index, and DNA damage were evaluated as genotoxic endpoints.

\section{MATERIALS AND METHODS}

\subsection{Animals}

Male Sprague-Dawley rats, weighing $120-150$ g of body weight were used. Standard laboratory food and water were provided ad libitum. Animal procedures were performed following the Ethics Committee of the National Research Centre and followed the recommendations of the National Institutes of Health Guide for Care and Use of Laboratory Animals (Publication No. 85-23, revised 1985).

\subsection{Drugs and Chemicals}

Malathion (Commercial grade, Naser Chemical Co., A.R.E), and citicoline $\left(\right.$ Somazina $^{\circledR}, \quad$ Ferrer International, S.A.) were used. Other chemicals and reagents were obtained from Sigma, USA.

\subsection{Study Design}

Rats were randomly allocated into five groups, six rats each. Group 1 (normal control) received saline intraperitoneally (i.p., $0.2 \mathrm{ml} / \mathrm{rat}$ ). Group 2-5 received malathion $(150 \mathrm{mg} / \mathrm{kg}$, i.p.). Following malathion injection, groups 3-5 received citicoline at doses of 10, 200, $300 \mathrm{mg} / \mathrm{kg}$, orally. Group 6 received citicoline alone at a dose of $300 \mathrm{mg} / \mathrm{kg}$ orally. On the second day, rats received a second dose of the above treatments and were euthanized by decapitation $2 \mathrm{~h}$ after drug administration. Brains were rapidly removed and dissected out on an ice-cold plate into different areas (cerebral cortex, striatum, and rest of brain tissue), weighed, washed with ice-cold phosphate-buffered saline ( $\mathrm{pH}$ 7.4), and stored at -80 ${ }^{\circ} \mathrm{C}$. The brain was homogenized with $0.1 \mathrm{M}$ phosphate buffer saline at $\mathrm{pH} 7.4$ to give a final concentration of $20 \% \mathrm{w} / \mathrm{v}$ for the biochemical analyses.

\subsection{Biochemical Analyses}

\subsubsection{Lipid Peroxidation}

Lipid peroxidation products in the brain homogenates were assayed by measuring the level of malondialdehyde (MDA) using the method of RuizLarrea et al. (1994) where the thiobarbituric acid reactive substances react with thiobarbituric acid to produce a red-colored complex having a peak absorbance at $532 \mathrm{~nm}$.

\subsubsection{Reduced Glutathione}

Reduced glutathione (GSH) was determined in brain homogenates using the method of Ellman et al. (1959). The procedure is based on the reduction of Ellman's reagent by -SH groups of GSH to form 2nitro-s-mercaptobenzoic acid, which is intense yellow and determined using a spectrophotometer at $412 \mathrm{~nm}$.

\subsubsection{Nitric Oxide}

Nitric oxide was determined using Griess reagent, according to the method of Moshage et al. (1995) where nitrite, a stable end product of nitric oxide 
radical, is mostly used as an indicator for the production of nitric oxide.

\subsubsection{Paraoxonase Activity}

Arylesterase activity of paraoxonase was measured spectrophotometrically in serum using phenylacetate as a substrate (Higashino et al., 1972; Watson et al., 1995).

\subsubsection{Butyrylcholinesterase Activity}

Butyrylcholinesterase activity was measured spectrophotometrically in serum using a commercially available kit (Ben Biochemical Enterprise, Milan, Italy). In this assay, cholinesterase catalyzes the hydrolysis of butyrylthiocholine, forming butyrate and thiocholine. The thiocholine reacts with dithiobis-nitrobenzoic acid (DTNB) forming a colored compound. The increase in absorbance in the unit time at $405 \mathrm{~nm}$ is proportional to the activity of the cholinesterase in the sample.

\subsubsection{Tumor necrosis factor (TNF- $\alpha)$}

Quantitative determination of brain TNF- $\alpha$ was performed using (Glory, USA) ELISA kit.

\subsection{Cytogenetic assays}

\subsubsection{Chromosome Aberration assay in Somatic Cells}

Rat femurs were collected and bone marrow cells were aspirated using saline solution. Metaphase spreads were prepared according to Brewen and Preston (1978).

\subsubsection{Micronucleus Test}

Bone marrow slides were prepared according to the method described by Krishna and Hayashi (2000). The bone marrow was washed with $1 \mathrm{ml}$ of fetal calf serum and then smeared on clean slides. The slides were left to air dry and then fixed in methanol for 5 minutes, followed by staining in May-Grunwald Giemsa for 5 minutes then washed in distilled water and mounted. For each animal, 2000 polychromatic erythrocytes (PCEs) were examined for the presence of micronucleated polychromatic erythrocytes (\%MnPCEs). Two hours before sacrifice, the animals were injected with $0.5 \mathrm{mg}$ of colchicine solution.

\subsubsection{Mitotic index determination}

The mitotic index was used to determine the rate of cell division. The mitotic activity of bone marrow cells was calculated by dividing the number of dividing cells (metaphase stage)/ 1000 cells/ animal (Moore et al., 2011).

\subsubsection{DNA Fragmentation Using Gel Electrophoresis Laddering Assay}

Apoptotic DNA fragmentation was qualitatively analyzed by detecting the laddering pattern of nuclear DNA as described according to Lu et al. (2002). Briefly, liver tissues were homogenized, washed in PBS, and lysed in $0.5 \mathrm{ml}$ of DNA extraction buffer (50 mM Tris-HCl, $10 \mathrm{mM}$ EDTA, $0.5 \%$ Triton, and $100 \mu \mathrm{g} / \mathrm{ml}$ proteinase $\mathrm{K}, \mathrm{pH} 8.0$ ) for overnight at 37 ${ }^{\circ} \mathrm{C}$. The lysate was then incubated with $100 \mu \mathrm{g} / \mathrm{ml}$ DNase-free RNase for $2 \mathrm{~h}$ at $37^{\circ} \mathrm{C}$, followed by three extractions of an equal volume of phenol/ chloroform $(1: 1 \mathrm{v} / \mathrm{v})$ and a subsequent re-extraction with chloroform by centrifuging at 15,000 rpm for $5 \mathrm{~min}$ at $4{ }^{\circ} \mathrm{C}$. The extracted DNA was precipitated in twovolume of ice-cold $100 \%$ ethanol with $1 / 10$ volume of $3 \mathrm{M}$ sodium acetate, $\mathrm{pH} 5.2$ at $-20{ }^{\circ} \mathrm{C}$ for $1 \mathrm{~h}$, followed by centrifuging at $15,000 \mathrm{rpm}$ for $15 \mathrm{~min}$ at $4{ }^{\circ} \mathrm{C}$. After washing with $70 \%$ ethanol, the DNA pellet was air-dried and dissolved in $10 \mathrm{mM}$ Tris$\mathrm{HCl} / 1 \mathrm{mM}$ EDTA, $\mathrm{pH}$ 8.0. The DNA was then electrophoresed on $1.5 \%$ agarose gel and stained with ethidium bromide in Tris/acetate/EDTA (TAE) buffer ( $\mathrm{pH}$ 8.5, $2 \mathrm{mM}$ EDTA, and $40 \mathrm{mM}$ Trisacetate). A 100-bp DNA ladder (Invitrogen, USA) was included as a molecular size marker and DNA fragments were visualized and photographed by exposing the gels to ultraviolet transillumination.

\subsubsection{Statistical Analysis}

Data are expressed as mean \pm SEM. Statistical significance was determined using an ANOVA, followed by Tukey-HSD post-hoc test.

\section{RESULTS}

\subsection{Biochemical Results}

\subsubsection{Butyrylcholinesterase Activity}

Malathion injection reduced serum $\mathrm{BChE}$ activity by 221.9\%. Co-administration of citicoline restored BChE activity dose-dependently (Table 1).

\subsubsection{Paraoxonase 1 Activity}

Injection of malathion suppressed serum PON1 activity by $57.6 \%$. Co-administration of citicoline improved PON1 activity in a dose-dependent manner up to control values (Table 1). 


\subsubsection{Oxidative stress}

Acute malathion intoxication markedly increased MDA levels by $137.4 \%$ in the cortex, $113.4 \%$ in the striatum, and by $112 \%$ in the subcortex A decline in the GSH level by $62.5 \%, 80 \%$, and $76.5 \%$ was found in the cortex, striatum, and subcortex after injection of malathion, whereas marked elevation of NO concentration by $82.1 \%, 127.5 \%$, and $202.4 \%$ was observed in these brain regions, respectively. Citicoline co-administered with malathion reduced MDA and markedly increased GSH concentration in investigated brain regions up to control values. Brain NO levels showed a significant decline following citicoline treatment (Table 2).

Table 1. Effect of citicoline on brain BChE activity in rats exposed to malathion.

\begin{tabular}{|l|l|l|l|l|l|l|}
\hline & Control & Malathion & $\begin{array}{l}\text { Malathion } \\
+ \text { Citicoline } \\
(100 \mathrm{mg} / \mathrm{kg})\end{array}$ & $\begin{array}{l}\text { Malathion } \\
+ \text { Citicoline } \\
(200 \mathrm{mg} / \mathrm{kg})\end{array}$ & $\begin{array}{l}\text { Malathion } \\
+ \text { Citicoline } \\
(300 \mathrm{mg} / \mathrm{kg})\end{array}$ & $\begin{array}{l}\text { Citicoline } \\
(300 \mathrm{mg} / \mathrm{kg})\end{array}$ \\
\hline $\mathrm{BChE}$ & $\begin{array}{l}45.1 \pm \\
7.6\end{array}$ & $\begin{array}{l}145.5^{\mathrm{a}} \pm \\
15.3^{\mathrm{a}}\end{array}$ & $61.0^{\mathrm{b}} \pm 6.9$ & $56.9^{\mathrm{b}} \pm 6.7$ & $43.4^{\mathrm{b}} \pm 5.9$ & $41.5 \pm 7.2$ \\
\hline PON-1 & $316 \pm 50$ & $134^{\mathrm{a}} \pm 9.2$ & $276^{\mathrm{b}} \pm 36$ & $292^{\mathrm{b}} \pm 31$ & $330^{\mathrm{b}} \pm 16$ & $451 \pm 76$ \\
\hline
\end{tabular}

${ }^{\text {a }}$ Significantly different from the control group at $p<0.05$.

${ }^{\mathrm{b}}$ Significantly different from malathion group at $p<0.05$.

Table 2. Effect of citicoline on brain oxidative stress in rats exposed to malathion.

\begin{tabular}{|c|c|c|c|c|c|c|}
\hline & Control & Malathion & $\begin{array}{l}\text { Malathion } \\
\text { +Citicoline } \\
(100 \mathrm{mg} / \mathrm{kg})\end{array}$ & $\begin{array}{l}\text { Malathion } \\
\text { +Citicoline } \\
(200 \mathrm{mg} / \mathrm{kg})\end{array}$ & $\begin{array}{l}\text { Malathion } \\
\text { +Citicoline } \\
(300 \mathrm{mg} / \mathrm{kg})\end{array}$ & Citicoline \\
\hline \multirow{4}{*}{$\begin{array}{l}\text { MDA } \\
\text { Cortex } \\
\text { Striatum } \\
\text { Subcortex }\end{array}$} & & & & & & \\
\hline & $\begin{array}{l}28.33 \pm \\
0.81\end{array}$ & $\begin{array}{ll}67.22^{\mathrm{a}} \quad \pm \\
13.81\end{array}$ & $\begin{array}{ll}30.18^{\mathrm{b}} & \pm \\
0.144 & \\
\end{array}$ & $\begin{array}{ll}32.58^{\mathrm{b}} & \pm \\
3.96 & \\
\end{array}$ & $28.9^{\mathrm{b}} \pm 1.88$ & $36.4 \pm 3.15$ \\
\hline & $\begin{array}{l}30.18 \pm \\
2.77\end{array}$ & $64.39^{\mathrm{a}} \pm 8$ & $\begin{array}{ll}33.33^{\mathrm{b}} & \pm \\
2.85 & \\
\end{array}$ & $\begin{array}{ll}30.88^{\mathrm{b}} & \pm \\
1.48 & \\
\end{array}$ & $\begin{array}{ll}28.66^{\mathrm{b}} & \pm \\
3.15 & \\
\end{array}$ & $\begin{array}{l}29.37 \\
2.29 \\
\end{array}$ \\
\hline & $\begin{array}{l}32.18 \pm \\
1.82\end{array}$ & $\begin{array}{ll}68.37^{\mathrm{a}} \quad \pm \\
0.29 & \\
\end{array}$ & $\begin{array}{ll}36.33^{\mathrm{b}} & \pm \\
1.43 & \\
\end{array}$ & $\begin{array}{ll}30.76^{\mathrm{b}} \quad \pm \\
1.48 & \\
\end{array}$ & $\begin{array}{ll}30.23^{\mathrm{b}} & \pm \\
9.15 & \end{array}$ & $\begin{array}{ll}30.42 & \pm \\
3.85 & \\
\end{array}$ \\
\hline \multicolumn{7}{|l|}{ GSH } \\
\hline Cortex & $\begin{array}{l}4.05 \pm \\
0.465\end{array}$ & $1.5^{\mathrm{a}} \pm 0.12$ & $3.8^{b} \pm 1.3$ & $4.2^{b} \pm 0.35$ & $4.8^{\mathrm{b}} \pm 0.27$ & $4.14 \pm 0.25$ \\
\hline Striatum & $\begin{array}{l}4.5 \quad \pm \\
0.058\end{array}$ & $\begin{array}{ll}0.9^{\mathrm{a}} & \pm \\
0.007 & \\
\end{array}$ & $3.6^{\mathrm{b}} \pm 0.079$ & $4.5^{\mathrm{b}} \pm 0.062$ & $6^{b} \pm 0.16$ & $4.7 \pm 0.3$ \\
\hline Subcortex & $\begin{array}{ll}5.1 & \pm \\
0.40 & \\
\end{array}$ & $1.2^{\mathrm{a}} \pm 0.10$ & $3.9^{b} \pm 0.9$ & $4.48^{\mathrm{b}} \pm 0.25$ & $5.35^{\mathrm{b}} \pm 0.3$ & $4.2 \pm 0.213$ \\
\hline \multicolumn{7}{|l|}{$\mathrm{NO}$} \\
\hline Cortex & $\begin{array}{ll}17.9 \quad \pm \\
3.3 & \\
\end{array}$ & $39^{a} \pm 1.5$ & $33.7^{\mathrm{b}} \pm 2.6$ & $30.7^{b} \pm 1.6$ & $26.6^{b} \pm 2.5$ & $20 \pm 2.4$ \\
\hline Striatum & $\begin{array}{ll}17.1 \quad \pm \\
0.8\end{array}$ & $38.6^{a} \pm 4.7$ & $25.4^{\mathrm{b}} \pm 1.1$ & $29.7^{b} \pm 2.4$ & $17.3^{b} \pm 2.3$ & $19 \pm 1.7$ \\
\hline Subcortex & $\begin{array}{ll}16.9 & \pm \\
0.2 & \end{array}$ & $51.1^{\mathrm{a}} \pm 1.9$ & $37.3^{b} \pm 3.0$ & $27.6^{b} \pm 3.3$ & $26.5^{\mathrm{b}} \pm 2.3$ & $21 \pm 2.34$ \\
\hline
\end{tabular}

${ }^{a}$ Significantly different from the control group at $p<0.05$.

${ }^{\mathrm{b}}$ Significantly different from malathion group at $p<0.05$. 


\subsubsection{TNF- $\alpha$}

In malathion-intoxicated rats, striatal TNF- $\alpha$ concentration markedly increased by $133 \%$ was found after injection of malathion. A dose-dependent decrease in striatal TNF- $\alpha$ was observed after treatment with citicoline (Table 3).

\subsection{Cytogenetic Results}

\subsubsection{Chromosome Analysis in Somatic Cells}

An increase in the frequency of structural aberrations (eg., chromatoid gaps, chromosomal gaps, breaks) aberrations was observed after malathion injection. These aberrations were decreased by treatment with citicoline dose-dependently (Table 4, Figure 1).

Table 3. Effect of citicoline on brain TNF- $\alpha$ in rats exposed to malathion.

\begin{tabular}{|l|l|l|l|l|l|l|}
\hline & Control & Malathion & $\begin{array}{l}\text { Malathion } \\
+ \text { Citicoline } \\
(100 \mathrm{mg} / \mathrm{kg})\end{array}$ & $\begin{array}{l}\text { Malathion } \\
+ \text { Citicoline } \\
(200 \mathrm{mg} / \mathrm{kg})\end{array}$ & $\begin{array}{l}\text { Malathion } \\
+ \text { Citicoline } \\
(300 \mathrm{mg} / \mathrm{kg})\end{array}$ & Citicoline \\
\hline TNF- $\alpha$ & \multicolumn{7}{|c|}{} & \\
\hline Cortex & $25 \pm 2.7$ & $\begin{array}{l}32.26 \\
0.26\end{array}$ & $26 \pm 1.55$ & $27 \pm 2.35$ & $26 \pm 3.45$ & $25 \pm 2.3$ \\
\hline Striatum & $\begin{array}{l}29.75 \pm \\
6\end{array}$ & $\begin{array}{l}74.5^{\mathrm{a}} \\
6.08\end{array}$ & $\begin{array}{l}31.58^{\mathrm{b}} \\
3.46\end{array}$ & $29.08^{\mathrm{b}} \pm 2.5$ & $27.9^{\mathrm{b}} \pm 2.25$ & $28 \pm 2.14$ \\
\hline Subcortex & $30 \pm 0.6$ & $38.5 \pm 2.75$ & $20 \pm 2.6$ & $21 \pm 2$ & $25.5 \pm 0.16$ & $24 \pm 1.6$ \\
\hline
\end{tabular}

${ }^{\text {a }}$ Significantly different from the control group at $p<0.05$.

${ }^{\mathrm{b}}$ Significantly different from malathion group at $p<0.05$. 
Table 4. Effect of citicoline on the frequency of chromosomal aberrations in rats exposed to malathion.

\begin{tabular}{|c|c|c|c|c|c|c|}
\hline \multirow[t]{2}{*}{ Groups } & \multicolumn{6}{|c|}{ Structural aberrations } \\
\hline & $\begin{array}{l}\text { Chromatid } \\
\text { gaps }\end{array}$ & $\begin{array}{l}\text { Chromosome } \\
\text { gaps }\end{array}$ & $\begin{array}{l}\text { Chromatid } \\
\text { breaks }\end{array}$ & Deletions & Fragments & endomitosis \\
\hline Control & $\begin{array}{l}0.80 \\
\pm \\
0.200\end{array}$ & $\begin{array}{l}0.00 \\
\pm \\
0.000\end{array}$ & $\begin{array}{l}0.00 \\
\pm \\
0.000\end{array}$ & $\begin{array}{l}0.00 \\
\pm \\
0.000\end{array}$ & $\begin{array}{l}0.40 \\
\pm \\
0.244\end{array}$ & $\begin{array}{l}0.00 \\
\pm \\
0.000\end{array}$ \\
\hline Malathion & $\begin{array}{l}7.20^{\mathrm{a}} \\
\pm \\
0.374\end{array}$ & $\begin{array}{l}3.80^{\mathrm{a}} \\
\pm \\
0.583\end{array}$ & $\begin{array}{l}3.20^{\mathrm{a}} \\
\pm \\
0.489\end{array}$ & $\begin{array}{l}3.00^{\mathrm{a}} \\
\pm \\
0.316\end{array}$ & $\begin{array}{l}3.80^{\mathrm{a}} \\
\pm \\
0.374\end{array}$ & $\begin{array}{l}3.60^{\mathrm{a}} \\
\pm \\
0.244\end{array}$ \\
\hline $\begin{array}{l}\text { Malathion + } \\
\text { citicoline } \\
(100 \mathrm{mg} / \mathrm{kg})\end{array}$ & $\begin{array}{l}2.40^{\mathrm{b}} \\
\pm \\
0.400\end{array}$ & $\begin{array}{l}0.80^{\mathrm{b}} \\
\pm \\
0.200\end{array}$ & $\begin{array}{l}0.60^{\mathrm{b}} \\
\pm \\
0.244\end{array}$ & $\begin{array}{l}0.40^{\mathrm{b}} \\
\pm \\
0.244\end{array}$ & $\begin{array}{l}2.20^{\mathrm{b}} \\
\pm \\
0.200\end{array}$ & $\begin{array}{l}1.80^{\mathrm{b}} \\
\pm \\
0.583\end{array}$ \\
\hline $\begin{array}{l}\text { Malathion + } \\
\text { citicoline } \\
(200 \mathrm{mg} / \mathrm{kg})\end{array}$ & $\begin{array}{l}1.60^{\mathrm{b}} \\
\pm \\
0.244\end{array}$ & $\begin{array}{l}0.40^{\mathrm{b}} \\
\pm \\
0.449\end{array}$ & $\begin{array}{l}0.20^{\mathrm{b}} \\
\pm \\
0.200\end{array}$ & $\begin{array}{l}0.00 \\
\pm \\
0.000\end{array}$ & $\begin{array}{l}2.40^{\mathrm{b}} \\
\pm \\
0.400\end{array}$ & $\begin{array}{l}2.20^{\mathrm{b}} \\
\pm \\
0.200\end{array}$ \\
\hline $\begin{array}{l}\text { Malathion + } \\
\text { citicoline } \\
(300 \mathrm{mg} / \mathrm{kg})\end{array}$ & $\begin{array}{l}1.20^{\mathrm{b}} \\
\pm \\
0.374\end{array}$ & $\begin{array}{l}0.80^{\mathrm{b}} \\
\pm \\
0.200\end{array}$ & $\begin{array}{l}0.80^{\mathrm{b}} \\
\pm \\
0.200\end{array}$ & $\begin{array}{l}0.80^{\mathrm{b}} \\
\pm \\
0.200\end{array}$ & $\begin{array}{l}0.40^{\mathrm{b}} \\
\pm \\
0.244\end{array}$ & $\begin{array}{l}0.60^{\mathrm{b}} \\
\pm \\
0.244\end{array}$ \\
\hline citicoline & $\begin{array}{l}0.40 \\
\pm \\
0.244\end{array}$ & $\begin{array}{l}0.40 \\
\pm \\
0.244\end{array}$ & $\begin{array}{l}0.20 \\
\pm \\
0.200\end{array}$ & $\begin{array}{l}0.20 \\
\pm \\
0.200\end{array}$ & $\begin{array}{l}0.40 \\
\pm \\
0.244\end{array}$ & $\begin{array}{l}0.40 \\
\pm \\
0.244\end{array}$ \\
\hline
\end{tabular}

${ }^{a}$ Significantly different from the control group at $p<0.05$.

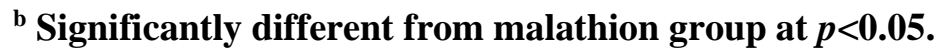



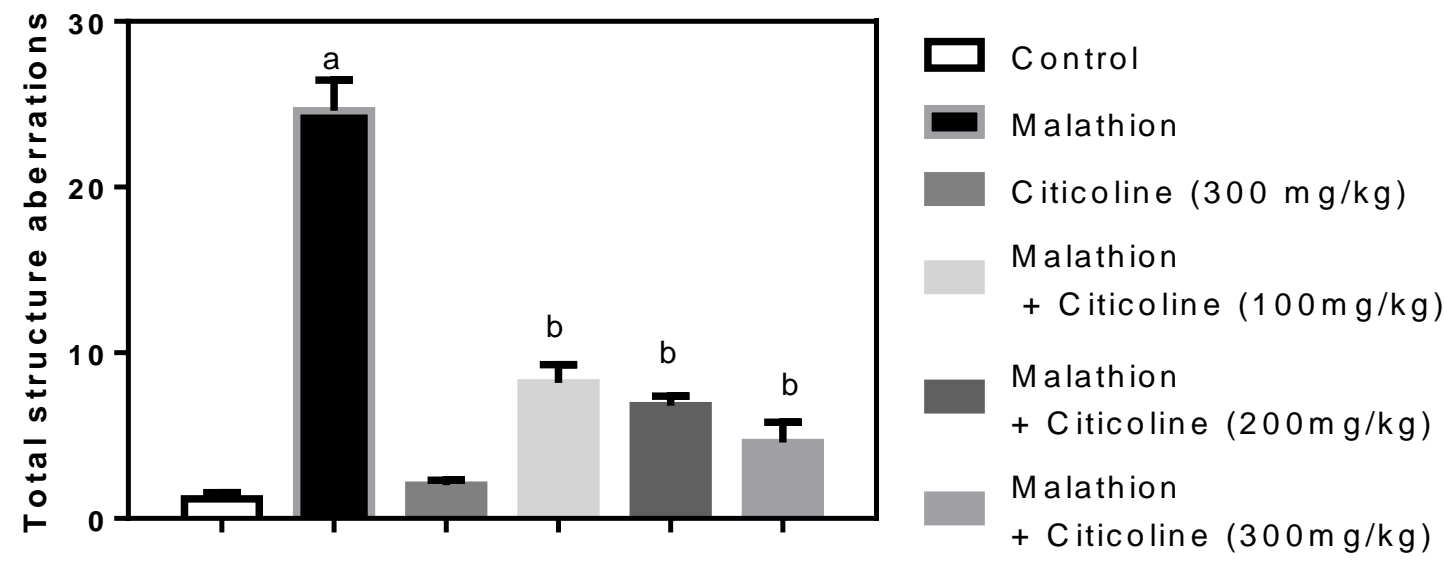

Figure (1). Effect of citicoline on total structural aberrations in rats exposed to malathion.

${ }^{\text {a }}$ Significantly different from the control group at $p<0.05$.

${ }^{\mathrm{b}}$ Significantly different from malathion group at $p<0.05$.

\subsection{DNA Studies}

\subsubsection{Micronucleus Test}

Injection of malathion increased the number of micronucleated polychromatic erythrocytes (MnPCE) and the ratio of normal chromatic erythrocytes/micronucleated polychromatic erythrocytes (NCE/MnPCE) (328.5\%). MnPCE number was decreased by $11 \%, 27.7 \%$, and $45.3 \%$ after treatment with citicoline at 100, 200, and 300 $\mathrm{mg} / \mathrm{kg}$, respectively (Figure $2 \mathrm{a}$, and b).

3.3.3. Mitotic index
A significant decrease in the mitotic index was recorded in animals receiving malathion (54\%). Treatment with citicoline at doses 100, 200, and 300 $\mathrm{mg} / \mathrm{kg}$ resulted in a dose-dependent increase in a mitotic index by $54 \%, 72 \%$, and $81 \%$, respectively (Figure 3).

\subsubsection{DNA Fragmentation Using Gel} Electrophoresis Laddering Assay

Malathion caused DNA fragmentation of liver cells and this was decreased by treatment with citicoline (Figure 4). 
(a)
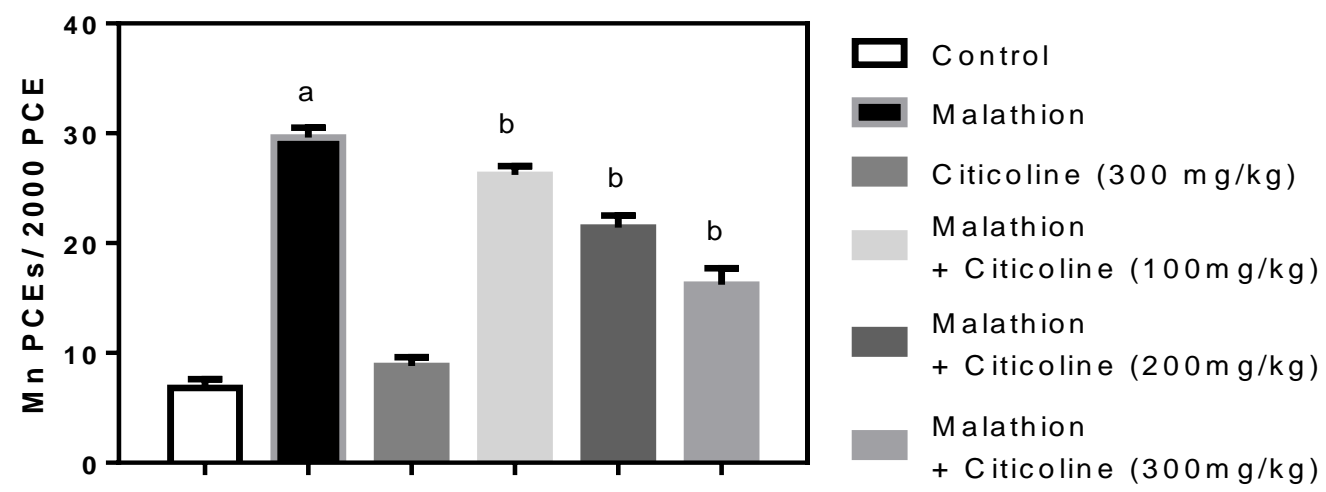

(b)
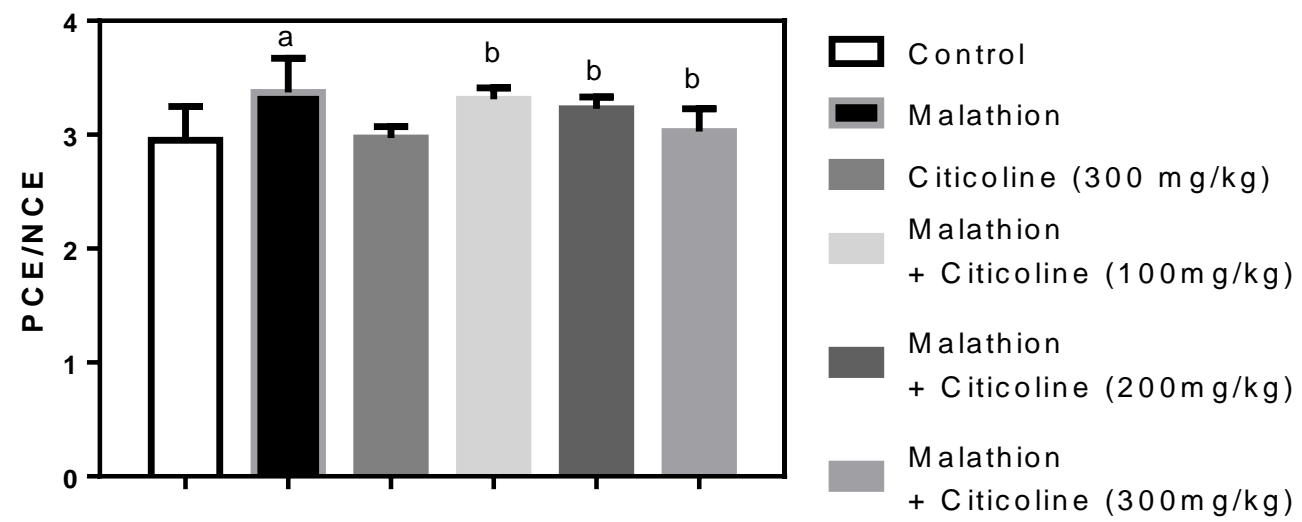

Figure (2) Effect of citicoline on (a) MnPCEs/2000PCE, and (b) PCE/NCE in rats exposed to malathion.

${ }^{a}$ Significantly different from the control group at $p<0.05$.

${ }^{\mathrm{b}}$ Significantly different from malathion group at $p<0.05$.
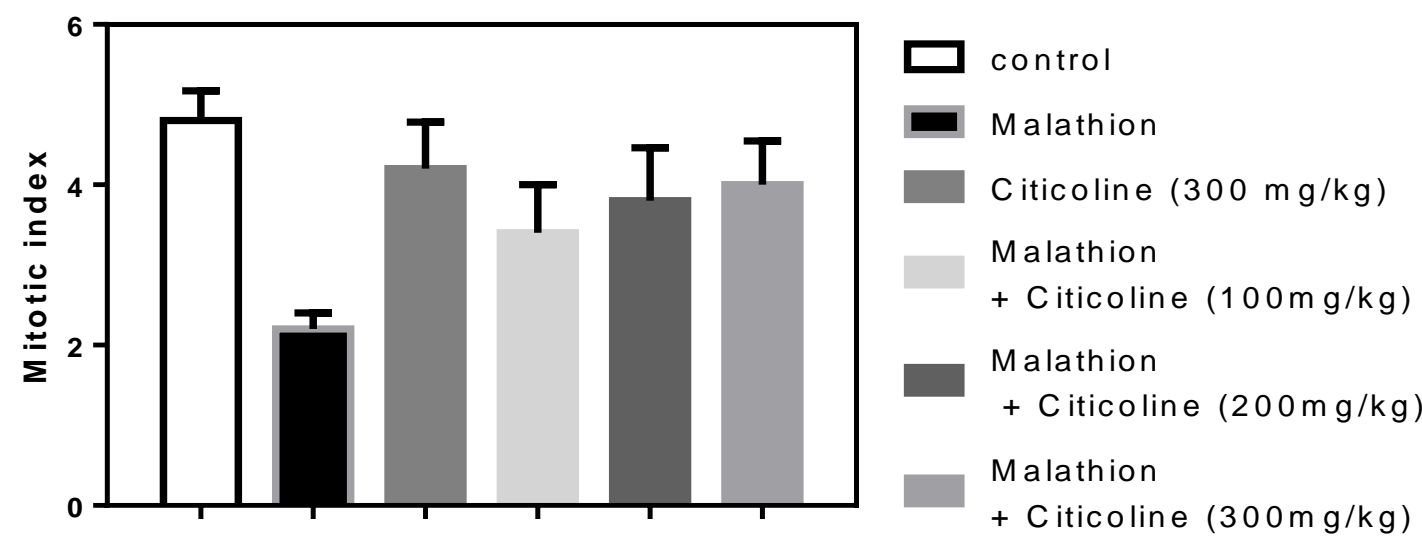

Figure (3). Effect of citicoline on a mitotic index in rats exposed to malathion.

a Significantly different from the control group at $p<0.05$.

${ }^{\mathrm{b}}$ Significantly different from malathion group at $p<0.05$. 
1
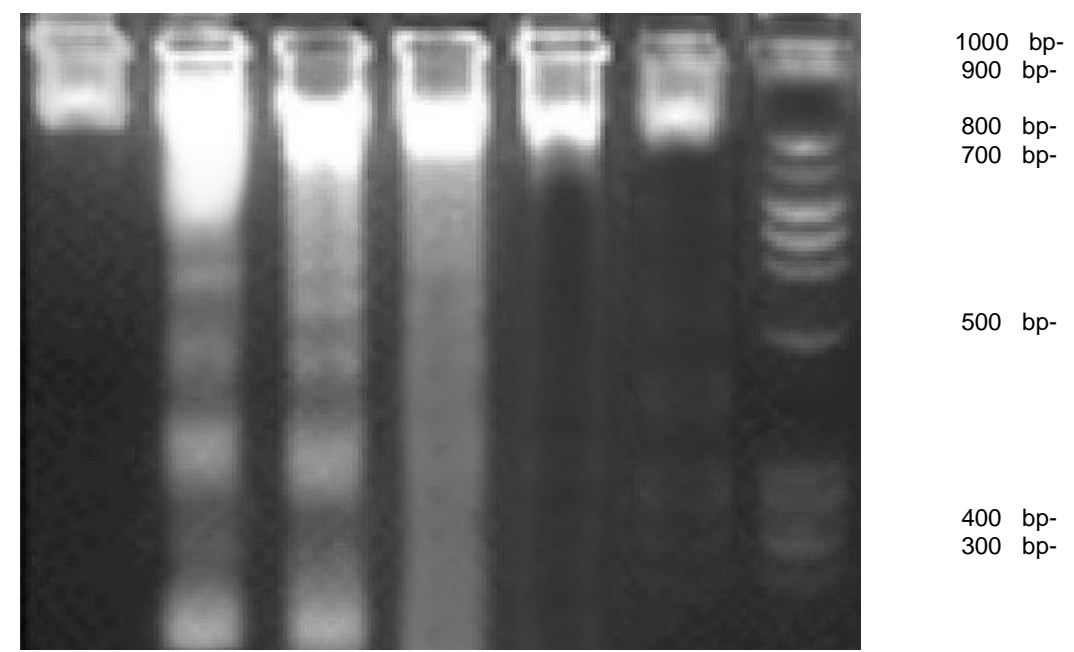

Figure (4): DNA fragmentation detected with agarose gel of DNA extracted from liver tissues of female rats by DNA gel electrophoresis laddering assay. Lane 1 represents control rats. Lane 2 represents rats treated with Malathion. Lanes 3-5 represent rats treated with Malathion plus 100, 200, and $300 \mathrm{mg} / \mathrm{kg}$ of Citicoline, respectively. Lane 6 represents rats treated with Citicoline. M represents DNA ladder in female rats treated with malathion $(M)$ and/or citicoline.

\section{DISCUSSION}

The results of the present study demonstrate the effectiveness of citicoline in protecting against neurotoxicity and genotoxicity in the rat model of acute malathion intoxication. As an initial assessment of biomarkers of malathion exposure, we examined serum activities of $\mathrm{BChE}$ and $\mathrm{PON}-1$ as potential biomarkers of OPs exposure (Jenner, 1994). In the present study, the activities of both $\mathrm{BChE}$ and $\mathrm{PON}$ 1 are profoundly declined after malathion exposure. Plasma cholinesterase (BChE) reflects acute exposure to OPs since it is reduced more rapidly and intensely than erythrocyte cholinesterase (AChE). $\mathrm{AChE}$ is considered as an accurate biomarker of lowintensity chronic exposure (ATSDR, 2017). Being highly reactive compounds, OPs can alter the function of important enzymes and proteins through oxidative reactions. The observed decline in serum PON-1 activity in the current study can be attributed to the inactivation of the enzyme by the pesticide or the enzyme is over consumed in conjugation reactions. The detoxification capacity of PON-1 is considered as a key link between environmental exposure to pesticides and various diseases since the peroxidase activity of PON1 can protect cells against a buildup of Ach (Furlong et al., 2005; Goswami et al., 2009).

Administration of citicoline recovered the activity of both BChE and PON-1, possibly via antioxidant mechanism and increasing phosphatidylcholine (PC) synthesis that acted synergistically to reactivate enzymes. Plataras and colleagues (2000) showed that incubation of brain homogenates with CDP-choline resulted in stimulating AChE activity by about 9, 15, and $21 \%$ for $0.1,0.5$, and $0.8 \mathrm{mM}$, respectively. The authors concluded that CDP-choline might improve inhibited AChE activity through the conversion of CDP-choline to PC which affects AChE more rapidly.

To examine the neuroprotective effect of citicoline on a malathion-induced neuronal injury, we tested brain oxidative stress biomarkers in different brain regions. 
Our results indicate that acute malathion exposure markedly increased MDA and NO and suppressed GSH levels in different brain regions. Also, malathion induced a significant increase in striatal TNF- $\alpha$ levels, dose-dependently.

Inhibition of cholinesterases is known to overstimulate nervous tissue and muscle, leading to depletion of high energy phosphates, and phosphocreatine followed by activation of phospholipases and caspases, enhancing the generation of ROS and activation of nitric oxide synthase (Milatovic, 2006). This activation results in the generation of nitric oxide $(\mathrm{NO})$ that reacts with the superoxide $\mathrm{O}^{2-}$ leading to the formation of OONO $^{-}$radical. Furthermore, NO impairs mitochondrial respiration leading to ATP depletion and thus, compromise the cell's capability to maintain energy levels (Gupta, 2001). Another source of ROS is the biotransformation reactions of malathion into maloxon. Furthermore, conjugation with GSH is a major route of detoxification of malathion, hence increasing the rate of detoxification can reduce GSH availability rendering the brain vulnerable to increased levels of oxidative and excitotoxic insults, and initiating neuronal cell death (Akhgari et al., 2003). Overproduction of ROS leads to neuronal injury and consequently to microglial activation which is associated with an increased release in proinflammatory cytokines such as interleukins and TNF- $\alpha$ that initiate neuronal injury and result in neurological impairment (Li et al., 2015).

This work results from corporate previous studies that reported that malathion exposure induces oxidative stress in serum, brain structures, and cerebrospinal fluid in experimental animals (Ahmed et al., 2000; Delgado et al., 2006; Fortunato et al., 2006; Akhgari et al., 2013).

In the present study, we demonstrated that citicoline exerted a marked neuroprotective effect against acute malathion intoxication that was evident in improved oxidative status via increasing GSH and decreasing MDA and NO, compared to malathion-exposed rats. Also, citicoline suppressed the increments in striatal TNF- $\alpha$.
Several effects are likely to contribute to the neuroprotective actions of citicoline. Citicoline can modulate the synthesis of GSH via the choline-Sadenosyl-L-methionine pathway (de la Cruz, 2002). Citicoline has been also shown to increase GSH and GSH reductase activity in the gerbil model of transient forebrain ischemia compared to the ischemia/saline group (Adibhatla et al., 2001). Citicoline enhances the activities of an antioxidant system such as GSH, and SOD activity (Qian et al., 2014), and reduced the generation of free radicals (Adibhatla et al., 2001). Furthermore, citicoline preserves neuronal membrane integrity through enhancing the synthesis of structural phospholipids, especially phosphatidylcholine, a key factor for cell membrane integrity (Zweifler, 2002; Saver, 2008), restoration of $\mathrm{Na}^{+} / \mathrm{K}^{+}-\mathrm{ATPase}$ activity (Secades and Frontera, 1995), and attenuation of phospholipase A2 activity (Adibhatla and Hatcher, 2003).

In the current study, we studied the genotoxic potential of malathion in rats, using chromosomal aberrations, micronucleus test, mitotic index, and DNA fragmentation as genotoxic endpoints. Our results indicate that acute malathion administration can yield an elevation in cytogenic damage, as evidenced by high percentages of structural chromosome aberrations, decreased mitotic index, and increase in DNA fragmentation confirming the high genotoxic potential of the pesticide.

The observed increase in cytogenic markers may indicate exposure of cells to mutagens and carcinogens, although this does not necessarily lead to adverse health outcomes. The percentages of structural chromosomal aberrations such as chromatid and chromosome gaps, chromatid breaks, deletions, fragmentation, and endomitosis in the bone marrow were significantly increased compared to the control group. The pesticide also increased the number of micronucleated polychromatic erythrocytes and the ratio of normal chromatic erythrocytes/micronucleated polychromatic erythrocytes. Micronuclei are acentric fragments or complete chromosomes that do not bind to the mitotic spindle during cytokinesis and are excluded from the nuclei. This can be attributed to chromosome rupture 
(clastogenesis) or spindle rupture (aneugenesis) (Moore et al., 2011).

The mitotic index (MI) was another parameter of cytogenetic damage of malathion that is very critical in estimating the rate of cell division. It is defined as "the proportion of cells undergoing mitosis (cell division) compared to the total number of cells". According to our results, a significant decrease was noticed in the mean MI values in malathion in treated groups compared to the control group. This could be due to a slower progression of cells from the S (DNA synthesis) phase to the $\mathrm{M}$ (mitosis) phase of the cell cycle. These results were confirmed by DNA laddering assay, a commonly used assay for visualizing the double-stranded oligonucleosomal DNA fragments on agarose gels

Epidemiological studies have linked occupational exposure of malathion to high frequencies of chromosome aberrations in peripheral blood (Balaji and Sasikala, 1993; Zeljezic and Garaj-Vrhovac, 2002) As reported, malathion-induced genotoxic damage encompasses mitotic index, sister chromatid exchanges (SCE), and chromosomal aberrations in studies performed on both animals and humans. Among exposed cotton field workers, it was detected that pesticides exhibited a decrease in mitotic index and cell cycle delay that was not found in the control group. Amer and colleagues (2002) demonstrated that malathion increased cytogenetic parameters dose-dependently in bone marrow cells of exposed mice. Comparable findings in other studies have shown that malathion doses of $2.5,5$, and $10 \mathrm{mg} / \mathrm{kg}$ caused a dose-dependent increase in chromosome aberration frequency. Evidence of a moderate cell cycle delay was also recorded in mice exposed to higher doses of malathion.

In the present study, citicoline was able to alleviate the genotoxic alterations induced by malathion. Previous studies have demonstrated that citicoline can attenuate pro-caspase and caspase- 3 activation, specific PARP-cleaved products of caspase activation, and DNA fragmentation in a rat model of middle cerebral artery occlusion (Krupinski et al., 2002). During apoptosis, the CDP-choline pathway is suppressed leading to decreasing the availability of
PtdCho essential for cell survival and proliferation (Morton et al., 2013). The synthesis of PtdCho is increased during the G1 and S-phase of the cell cycle to coincide with duplication of other cellular components in preparation for mitosis. Citicoline, through increased synthesis of PtdCho, can attenuate the apoptotic cascade.

\section{CONCLUSION}

In summary, the present data indicate that acute intoxication with malathion induced neurodegenerative changes in rats as well as significant structural chromosomal aberrations in somatic cells and increased DNA fragmentation in the bone marrow and liver cells. Our results suggest that citicoline administered in conjunction with malathion was capable of alleviating the neurotoxicity and genotoxicity due to malathion exposure in rats which might prove valuable in combination with the standard therapeutic interventions in the management of populations at risk who are exposed to malathion and probably also other organophosphates. Besides, citicoline could be suggested as a prophylactic measure against long term toxicities of OPs.

\section{CONFLICTS OF INTEREST}

The authors declare that there are no conflicts of interest.

\section{REFERENCES}

Abd El AL, A.H., Fawzi, M.M., AL-Khafif, M.A., El-Zemaity, M.E.(2016). Epidemiological Study of Organophosphorus Compounds Insecticides Types Related To Acutely Intoxicated Patients Presented To Poison Control Center (PCC-ASU)-Egypt. IOSRJESTFT, 10 (6): 72-78. DOI: 10.9790/24021006037278

Abdollahi, M., Karami-Mohajeri, S.(2012). A comprehensive review on experimental and clinical findings in intermediate syndrome caused by organophosphate poisoning. Toxicol Appl Pharmacol., 258(3):309-14. DOI: 10.1016/j.taap.2011.11.014. 
Abdou, K.A., Abo El-Atta, H.M.(2018). Epidemiology of Pesticides in Developing Countries. Adv Clin Toxicol., 3(1): 1-8.

Adibhatla, R.M., Hatcher, J.F.(2003). Citicoline decreases phospholipase A2 stimulation and hydroxyl radical generation in transient cerebral ischemia. J Neurosci Res.,73(3):308-15. DOI:10.1002/jnr.10672

Adibhatla, R.M., Hatcher, J.F.(2005). Cytidine 5'diphosphocholine (CDP-choline) in stroke and other CNS disorders. Neurochem Res., 30(1):15-23. PMID:15756928

Adibhatla, R.M., Hatcher, J.F., Dempsey, R.J.(2001). Effects of citicoline on phospholipid and glutathione levels in transient cerebral ischemia. Stroke., 32(10):2376-81. PMID:11588329

Ahmed, R.S., Seth, V., Pasha, S.T., Banerjee B.D.(2000). Influence of dietary ginger (Zingiber officinales Rosc) on oxidative stress induced by malathion in rats. Food Chem Toxicol., 38(5):44350 .

Akhgari, M., Abdollahi, M., Kebryaeezadeh, A., Hosseini, R., Sabzevari, O.(2003). Biochemical evidence for free radical-induced lipid peroxidation as a mechanism for subchronic toxicity of malathion in blood and liver of rats. Hum Exp Toxicol., 22(4):205-11.

Amer, S.M., Fahmy, M.A., Aly, F.A., Farghaly, A.A. (2002). Cytogenetic studies on the effect of feeding mice with stored wheat grains treated with malathion. Mutat Res., 513(1-2):1-10. PMID:11719084

Andreotti, G., Freeman, L.E., Hou, L., Coble, J., Rusiecki, J., Hoppin, J.A., Silverman, D.T., Alavanja, M.C.(2009). Agricultural pesticide use and pancreatic cancer risk in the Agricultural Health Study Cohort. Int J Cancer., 124(10):2495-500. DOI: 10.1002/ijc.24185.

Astiz, M., Arnal, N., de Alaniz, M.J., Marra, C.A.(2011). Occupational exposure characterization in professional sprayers: clinical utility of oxidative stress biomarkers. Environ Toxicol Pharmacol., 32(2):249-58. DOI: 10.1016/j.etap.2011.05.010.

Balaji, M., Sasikala, K.(1993). Cytogenetic effect of malathion in vitro culture of human peripheral blood. Mutat Res., 301(1):13-7. PMID:7677938

Baris, D., Silverman, D.T., Brown, L.M., Swanson, G.M., Hayes, R.B., Schwartz, A.G., Liff, J.M., Schoenberg, J.B., Pottern, L.M., Greenberg, R.S., Stewart, P.A.(2004). Occupation, pesticide exposure and risk of multiple myeloma. Scand J Work Environ Health., 30(3):215-22. PMID: 15250650

Başkaya, M.K., Doğan, A., Rao, A.M., Dempsey, R.J.(2000). Neuroprotective effects of citicoline on brain edema and blood-brain barrier breakdown after traumatic brain injury. J Neurosurg., 92(3):448-52.

Beane Freeman, L.E., Bonner, M.R., Blair, A., Hoppin, J.A., Sandler, D.P., Lubin, J.H., Dosemeci, M., Lynch, C.F., Knott, C., Alavanja, M.C.(2005). Cancer incidence among male pesticide applicators in the Agricultural Health Study cohort exposed to diazinon. Am J Epidemiol., 162(11):1070-9. DOI: 10.1093/aje/kwi321

Bertrand, K.A., Spiegelman, D., Aster, J.C., Altshul, L.M., Korrick, S.A., Rodig, S.J., Zhang, S.M., Kurth, T., Laden, F.(2010). Plasma organochlorine levels and risk of non-Hodgkin lymphoma in a cohort of men. Epidemiology, 21(2):172-80.

DOI:

10.1097/EDE.0b013e3181cb610b.

Bonner, M.R., Williams, B.A., Rusiecki, J.A., Blair, A., Beane Freeman, L.E., Hoppin, J.A., Dosemeci, M., Lubin, J., Sandler, D.P., Alavanja, M.C.(2010). Occupational exposure to terbufos and the incidence of cancer in the Agricultural Health Study. Cancer Causes Control., 21(6):871-7. DOI: 10.1007/s10552-010-9514-9.

Brewen, J.G., Preston, R.J. (1978). Radiationinduced chromosome aberrations in somatic and 
germ cells of the male marmoset. Primates Med.,10:199-204. PMID:417321

Chen, Y.(2012). Organophosphate-induced brain damage: mechanisms, neuropsychiatric and neurological consequences, and potential therapeutic strategies. Neurotox., 33(3):391-400. DOI: 10.1016/j.neuro.2012.03.011.

De La Cruz, J.P., Villalobos, M.A., Cuerda, M.A., Guerrero, A., González-Correa, J.A., Sánchez De La Cuesta, F. (2002). Effects of S-adenosyl-Lmethionine on lipid peroxidation and glutathione levels in rat brain slices exposed to reoxygenation after oxygen-glucose deprivation. Neurosci Lett., 318(2):103-7. PMID:11796196

Delgado, E.H., Streck, E.L., Quevedo, J.L., DalPizzol, F. (2006). Mitochondrial respiratory dysfunction and oxidative stress after chronic malathion exposure. Neurochem Res., 31(8):1021-5.

Deshpande, L.S., Carter, D.S., Blair, R.E., DeLorenzo, R.J. (2010). Development of a prolonged calcium plateau in hippocampal neurons in rats surviving status epilepticus induced by the organophosphate diisopropylfluorophosphate. Toxicol Sci., 116(2):623-31. DOI: 10.1093/toxsci/kfq157.

Ellman GL.Tissue sulfhydryl groups. Arch Biochem Biophys. 1959; 82(1):70-7. PMID:13650640.

Furlong, C.E., Cole, T.B., Walter, B.J., Shih, D.M., Tward, A., Lusis, A.J., Timchalk, C., Richter, R.J., Costa, L.G.(2005). Paraoxonase 1 (PON1) status and risk of insecticide exposure. J Biochem Mol Toxicol., 19(3):182-3.

Gauthier, E., Fortier, I., Courchesne, F., Pepin, P., Mortimer, J., Gauvreau, D.(2001). Environmental pesticide exposure as a risk factor for Alzheimer's disease: a case-control study. Environ Res., 86(1):3745. DOI:10.1006/enrs.2001.4254.

Goswami, B., Tayal, D., Gupta, N., Mallika, V.(2009). Paraoxonase: a multifaceted biomolecule.
Clin Chim Acta., 410(1-2):1-12. DOI: 10.1016/j.cca.2009.09.025.

Grieb, P.(2014). Neuroprotective properties of citicoline: facts, doubts and unresolved issues. CNS Drugs., 28(3):185-93. DOI: 10.1007/s40263-0140144-8.

Guillette, E.A., Meza, M.M., Aquilar, M.G, Soto, A.D., Garcia, I.E.(1998). An anthropological approach to the evaluation of preschool children exposed to pesticides in Mexico. Environ Health Perspect., 106(6):347-53.

DOI: 10.1289/ehp. 98106347

Gupta, R.C., Milatovic, D., Dettbarn, W.D.(2001). Depletion of energy metabolites following acetylcholinesterase inhibitor-induced status epilepticus: protection by antioxidants. Neurotoxicology., 22(2):271-82.

Higashino, K., Takahashi, Y., Yamamura, Y.(1972). Release of phenyl acetate esterase from liver microsomes by carbon tetrachloride. Clin Chim Acta., 41:313-20. PMID:4645240

https://www.atsdr.cdc.gov/2017dchiannualreport/ind ex.html (accessed 27 April 2019)

Hurtado, O., Cárdenas, A., Pradillo, J.M., Morales, J.R., Ortego, F., Sobrino, T., Castillo, J., Moro, M.A., Lizasoain, I.(2007). A chronic treatment with CDP-choline improves functional recovery and increases neuronal plasticity after experimental stroke. Neurobiol Dis., 26(1):105-11.

Jenner, P.(1994). Oxidative damage in neurodegenerative disease. Lancet., 344(8925):7968.

Jenner, P.(2001). Parkinson's disease, pesticides and mitochondrial dysfunction. Trends Neurosci. , 24(5):245-7. PMID:11311359

Koutros, S., Lynch, C.F., Ma, X., Lee, W.J., Hoppin, J.A., Christensen, C.H., Andreotti, G., Freeman, L.B., Rusiecki, J.A., Hou, L., Sandler, D.P., Alavanja, M.C. (2009). Heterocyclic aromatic amine pesticide use and human cancer risk: results 
from the U.S. Agricultural Health Study. Int J Cancer., 124(5):1206-12. DOI: 10.1002/ijc.24020.

Krishna, G., Hayashi, M.(2000). In vivo rodent micronucleus assay: protocol, conduct and data interpretation. Mutat Res., 455(1-2):155-66. PMID: 11113474

Krupinski, J., Ferrer, I., Barrachina, M., Secades, J.J., Mercadal, J., Lozano, R.(2002). CDP-choline reduces pro-caspase and cleaved caspase-3 expression, nuclear DNA fragmentation, and specific PARP-cleaved products of caspase activation following middle cerebral artery occlusion in the rat. Neuropharmacol., 42(6):846-54. PMID: 12015211

Levin, H.S.(1991). Treatment of postconcussional symptoms with CDP-choline. J Neurol Sci., 103 Suppl:S39-42.

Li, Y., Lein, P.J., Ford, G.D., Liu, C., Stovall, K.C., White, T.E., Bruun, D.A., Tewolde, T., Gates, A.S., Distel, T.J., Surles-Zeigler, M.C., Ford, B.D.(2015). Neuregulin-1 inhibits neuroinflammatory responses in a rat model of organophosphate-nerve agent-induced delayed neuronal injury. J Neuroinflammation., 12:64. DOI: 10.1186/s12974-015-0283-y.

Lu, T., Xu, Y., Mericle, M.T., Mellgren, R.L.(2002). Participation of the conventional calpains in apoptosis. Biochim Biophys Acta., 1590(1-3):16-26. PMID:12063165

Milatovic, D., Gupta, R.C., Aschner, M.(2006). Anticholinesterase toxicity and oxidative stress. Sci World J., 28:6:295-310.

Mills, P.K., Yang, R.C.(2007). Agricultural exposures and gastric cancer risk in Hispanic farm workers in California. Environ Res., 104(2):282-9. DOI:10.1016/j.envres.2006.11.008

Moore, P.D., Patlolla, A.K., Tchounwou, P.B.(2011). Cytogenetic evaluation of malathioninduced toxicity in Sprague-Dawley rats. Mutat Res., 725(1-2):78-82. DOI: 10.1016/j.mrgentox.2011.07.007.
Morton, C.C., Aitchison, A.J., Gehrig, K., Ridgway, N.D.(2013). A mechanism for suppression of the CDP-choline pathway during apoptosis. J Lipid Res., 54(12):3373-84. DOI:10.1194/jlr.M041434

Moshage, H., Kok, B., Huizenga, J.R., Jansen, P.L.(1995). Nitrite and nitrate determinations in plasma: a critical evaluation. Clin Chem., 41(6 Pt 1):892-6. PMID:7768008

Orsi, L., Delabre, L., Monnereau, A., Delval, P., Berthou, C., Fenaux, P., Marit, G., Soubeyran, P., Huguet, F., Milpied, N., Leporrier, M., Hemon, D., Troussard, X., Clavel, J.(2009). Occupational exposure to pesticides and lymphoid neoplasms among men: results of a French case-control study. Occup Environ Med., 66(5):291-8. DOI: 10.1136/oem.2008.040972.

Plataras, C., Tsakiris, S., Angelogianni, P.(2000). Effect of CDP-choline on brain acetylcholinesterase and $\mathrm{Na}(+), \mathrm{K}(+)$-ATPase in adult rats. Clin Biochem., 33(5):351-7. PMID:11018686

Possamai, F.P., Fortunato, J.J., Feier, G., Agostinho, F.R., Quevedo, J., Wilhelm Filho, D., Dal-Pizzol, F.(2007). Oxidative stress after acute and sub-chronic malathion intoxication in Wistar rats. Environ Toxicol Pharmacol., 23(2):198-204. DOI: 10.1016/j.etap.2006.09.003.

Qian, K., Gu, Y., Zhao, Y., Li, Z., Sun, M.(2014). Citicoline protects brain against closed head injury in rats through suppressing oxidative stress and calpain over-activation. Neurochem Res., 39(7):1206-18. DOI: 10.1007/s11064-014-1299-x.

Rohlman, D.S., Anger, W.K., Lein, P.J. (2011). Correlating neurobehavioral performance with biomarkers of organophosphorous pesticide exposure. Neurotoxicology., 32(2):268-76. DOI: 10.1016/j.neuro.2010.12.008.

Ruiz-Larrea, M.B., Leal, A.M., Liza, M., Lacort, M., de Groot, H. (1994). Antioxidant effects of estradiol and 2-hydroxyestradiol on iron-induced 
lipid peroxidation of rat liver microsomes. Steroids., 59(6):383-8. PMID:7940617

Saver, J.L. (2008). Citicoline: update on a promising and widely available agent for neuroprotection and neurorepair. Rev Neurol Dis., 5(4):167-77. PMID: 19122569

Secades J.J.(2016). Citicoline: pharmacological and clinical review, 2016 update. Rev Neurol., 63(S03):S1-S73. PMID:28417449

Secades, J.J. (2011). Citicoline: pharmacological and clinical review, 2010 update. Rev Neurol., 52 Suppl 2:S1-S62. PMID:21432836

Secades, J.J., Frontera, G.(1995). CDP-choline: pharmacological and clinical review. Methods Find Exp Clin Pharmacol., 17 Suppl B:1-54. PMID:8709678

Singh, A.K., Jiang, Y.(2003). Lipopolysaccharide (LPS) induced activation of the immune system in control rats and rats chronically exposed to a low level of the organothiophosphate insecticide, acephate. Toxicol Ind Health., 19(2-6):93-108.

Warach, S., Pettigrew, L.C., Dashe, J.F., Pullicino, P., Lefkowitz, D.M., Sabounjian, L., Harnett K.,
Schwiderski, U., Gammans, R.(2000). Effect of citicoline on ischemic lesions as measured by diffusion-weighted magnetic resonance imaging. Citicoline 010 Investigators. Ann Neurol., 48(5):71322.

Watson, A.D., Berliner, J.A., Hama, S.Y., La Du, B.N., Faull, K.F., Fogelman, A.M., Navab, M. (1995). Protective effect of high density lipoprotein associated paraoxonase. Inhibition of the biological activity of minimally oxidized low density lipoprotein. J Clin Invest., 96(6):2882-91. DOI:10.1172/JCI118359

WHO Chemical Safety - Activity Report 2018 https://www.who.int/ipcs/IPCSActivityReport2018. pdf?ua=1

Zeljezic, D., Garaj-Vrhovac, V.(2002). Sister chromatid exchange and proliferative rate index in the longitudinal risk assessment of occupational exposure to pesticides. Chemosphere., 46(2):295303. PMID: 11827288

Zweifler, R.M.(2002). Membrane stabilizer: citicoline. Curr Med Res Opin.,18 Suppl 2:s14-7. 